\title{
KARAKTERISTIK RAGAM GERAK DAN TATA RIAS-BUSANA TARI NGREMO SEBAGAI WUJUD PRESENTASI SIMBOLIS
}

SOSIO KULTURAL

\section{Wahyudiyanto}

\section{Jurusan Tari STKW Surabaya}

\section{Abstract}

Ngremo dance is presented to begin Ludruk performance. In its course, the theme of the dance is moving from ritual to political one so that the present growth looks like soldier dance. The heroic value embodied in the dance theme is identified as the spirit of struggle to get independence. The heroic theme is visualized in the dance movement, costume and makeup. In the movemen aspect, the changes are from soft to fast speed, and supple to stiff moves. The costume is adopted from East Javanese prince's attributes worn in the independence war. Ngremo dance, which spreads around Surabaya, therefore represents the imaginary figure of Cakraningrat and the gallant, authoritative and resolute Sawunggaling.

Key words: Ngremo, characteristic and heroic

\section{A. Pendahuluan}

Tari Ngremo adalah tarian khas Jawa Timur berfungsi untuk mengawali pertunjukan Ludruk. Karena sebagai pembuka Ludruk maka dinamai juga tari Ludruk. Masih banyak sebutan lain seperti tari rena-rena, tari gembira, tari Ngremo Somogambar, tidak lain karena tarian ini mengalami perjalanan panjang sejajar dengan perjalanan sosio kultural masyarakat pembentuknya. Pada awal kemunculannya (1920-an) tarian ini bersifat religiuas, kemudian sebagai penghibur masyarakat. Masih nampak sangat sederhana dilihat dari aspek gerak, busana, dan pola pemanggungannya. Kala itu tari Ngremo tidak menunjukkan karakteristik yang jelas, kecuali hanya menampilkan gerak-gerak yang tersusun secara konfensional ( Hidajat. 2001. 115). Pada perkembangan selanjutnya ketika tari Ngremo dan Ludruk bersentuhan dengan realitas politik masa pergerakan, tari Ngremo memantapkan diri menjadi tarian yang khas sebagai tari dengan tema keprajuritan.

Meskipun Jombang diduga sebagai kelahiran pertunjukan Ludruk tetapi Surabaya merupakan pusat pertumbuhan teater ini. Kenyataan ini dapat dilihat dari Ludruk Sandiwara atau Sandiwara Ludruk yang datang dari Jombang ke Surabaya sekitar tahun 1931. Lakon yang sangat populer waktu itu adalah "Siti Muninggar Pendekar Wanita" ( Hendrowinoto, 1887: 21). Sejalan dengan kondisi politik perjuangan maka Ludruk Sandiwara dikenal dengan Ludruk perjuangan. Cak 
Durasim dengan kidungan Ngremo sangat berani mengkritik pemerintahan kolonial Jepang di Indonesia sehingga Cak Durasim harus keluar masuk penjara tentara Jepang di Surabaya yang akhirnya mati setelah keluar dari penjara (Supriyanto, 1992: 8)

Perjuangan Cak Durasim dalam menentang pendudukan Jepang di Indonesia merupakan tonggak sejarah tari Ngremo memasuki wilayah politik praktis. Melalui kidungan "bekupon omahe dara, melok Nippon tambah sengsara" tari Ngremo mulai menegaskan identitas tematiknya. Bersamaan dengan itu Cak Munali Pattah dengan perkumpulan Alap-alap-nya berjuang untuk membangkitkan semangat para rakyat pejuang dengan gongseng melingkar d kaki kanan (Prakosa, 2002: 28). Kenyataan empiris para seniman untuk melibatkan diri secara praktis dalam perjuangan meraih, menegakkan dan merebut kembali kemerdekaan merupakan embrio dari kelahiran ide tematik tari Ngremo ini. Hal ini dapat dicermati dalam masa perkembangan berikutnya pada saat mana tari Ngremo menampakkan diri sebagai figur prajurit pejuang.

Cakraningrat dan Sawunggaling adalah tokoh-tokoh bangsawan pejuang legendaris di Jawa Timur dijadikan orientasi perwujudan ide-ide (figur pejuang) tari Ngremo. Visualisasi tokoh-tokoh idola tersebut nampak sekali pada karakteristik yang hadir melalui tata rias dan tata busana. Dengan demikian tar Ngremo yang menggali figur para pangeran pejuang setempat merupakan bentuk artikulasi para seniman Ngremo atas pergulatannya dengan politik pergerakan Karenanya tari Ngremo ini berkembang dengan pesat di wilayah politik perjuangan yakni kota Surabaya dan Jawa Timur pada umumnya.

Ketika Ludruk dalam binaan institusi militer (melalui Dam VII Brawijaya Malang tahun 1960-an sampai dengan 1980-an) Ludruk perkembang pesat dan mendapatkan dukungan dari masyarakat yang cukup signifikan. Para Penari Ngremo ludruk berlomba-lomba untuk menegaskan karakteristik tar Ngremo dengan cara sendiri-sendiri. Sebagai mana pengakuan seorang penari Ngremo dari Malang (Cak Said Djajudi) yang sejak tahun 1930 mengaku bahwa tari Ngremo yang dipelajari berasal dari Cak Mimin, (pengreman dari Ludruk Surabaya) meskipun tidak jauh berbeda dengan Ngremo Malang yang lebih banyak variasi geraknya (Hidajat. 2001:115). Demikian juga pengakuan Munali Pattah (penari Ngremo khas Ngremo Surabaya), bahwa pernah penari-penari Ngremo dari Jombang belajar bersama tentang tari Ngremo yang kemudian kembali ke daerahnya dengan khas penari masing masing (Munali Pattah. 2001. Wawancara, Pebruari 18)

Tulisan ini ingin menggali karakteristik Tari Ngremo yang berkembang $\mathrm{d}$ Surabaya dan sekitarnya dilihat dari visualiasi bentuk fisik yang meliputi aspek gerak dan tata rias busana. Gerak yang berubah dari lembut gemulai menjadi cepa dan tegas, demikian pula tata rias dan busana yang pada perkembangan mutakhir mengidentifikasi tokoh imajiner pejuang setempat seperti Cakraningrat tokoh legendaris dari Madura dan Sawunggaling dari Surabaya. Kegiatan budaya seperti ini adalah wujud sapaan seni sebagai artikulasi estetik atas kultur merupakan keinginan wajar dari kegiatan membudaya yang selanjutnya melahirkan monumen bergerak berupa karya tari. Demukian ini bahwa kesenian tari sebagai kristalisasi dari kegiatan budaya masyarakat merupakan simbolisasi nilai-nilai kuturalnya.

\section{B. Tari Ngremo sebagai Wujud Presentasi Simbolis Sosio-Kultural}

Potensi manusia untuk membuat simbolisasi ada dua macam: diskursus dan presentasi. Susunan dari rangkaian kata-kata membuat simbol diskursus menjadi berarti tetapi datar dalam struktur. Sedangkan Simbol presentasi bersifat kiasan dan menampilkan esensi dari rasa pikiran melalui penggunaan daya khayalan dan ilusi. (Langer 1942 dalam Hawkins, 2002: 3-4). Dalam hal ini seniman lebih condong pada presentasi simbolik untuk menyatakan ekspresinya. Karenanya koreografi merupakan wujud representasi dari simbolisasi

Dalam kaitan pembentukan karya (koreografi) tari ini, Murgianto (1986: 144) menyatakan:

'Penata tari mengungkapkan apa saja yang ia rasakan tentang dirinya sendiri, dari orang lain, atau tentang kesadaran terhadap lingkungan atau hubungannya dengan Tuhan, ia dapat mengambil inspirasi dari peristiwa sehari-hari baik dalam kehidupan jasmani maupun dari sumber-sumber pengalaman batin yang terdalam dan membentuknya sebagai ide tarinya'.

Kesadaran seniman terhadap lingkunan menimbulkan sikap tertentu. Sikap demikian itu semata-mata untuk memenuhi kebutuhan hidup yang lebih baik dan sikap itulah yang melatar belakangi manusia berbudaya. Dengan demikian wujud suatu kesenian sebagai pengalaman berbudaya merupakan salah satu ungkap kehidupan yang melingkupinya. Tari Ngremo sebagai ciri komposisi koreografi, spesifikasi genre, dan sifat personalnya dipahami sebagai wujud pengalaman kemanusiaan dengan lingkungannya teraktualisasikan ke dalam budaya tari. Sebagai sebuah bentuk ekspresi estetik maka tari Ngremo mengusung sejumlah perwujudan dari beberapa ide dasar meliputi: aspek fisik kinestetik, auditif, visual organik dan ideasi tentang sistem nilai normatif masyarakat. Beberapa ide dasar inilah kemudian terbentuk dalam struktur menghadirkan karakteristik yang khas dalam panggung pertunjukan.

Karakter merupakan cerminan dari kesatuan garap elemen dasar tari yang membentuk keindahan tari. Pengertian karakter meliputi konstitusi jasmaniah, yaitu keadaan jasmaniah secara fisiologi merupakan sifat bawaan sejak lahir. Tipologi, dalam arti temperamen yang merupakan sifat seseorang yang 
disebabkan latar belakang keturunan, kondisi emosi yang berpengaruh pada kecepatan bereaksi, dan kualitas kekuatan gerak, kesesuaian dengan suasana hatinya, serta karakter sebagai watak yang merupakan wujud dari tingkah laku atau tindakan yang sudah mempribadi (Tasman, 1996: 24-26).

Pengertian karakteristik yang dibangun oleh ketiga aspek kemanusiaan tersebut dalam perspektif tari Ngremo melebur dalam bangunan rasa sebaga suasana dramatik. Pemahaman karakter yang demikian itu menunjuk pada kualitas yang dipersamakan dengan kemampuan serapan indra perasa merupakan makna dari rasa keindahan yang terpancar dalam pencapaian kualitas tari Ngremo. Keindahan rasa yang terpancar dari nilai-niali yang hidup dalam masyarakat itulah karakter tari Ngremo dapat diidentifikasi.

Tari Ngremo sebagai wujud ekspresi nilai-nilai yang hidup lebih menampakkan sikap tegas, keras, cepat, sigap yang tetap dalam pengemdalian merupakan ciri-ciri ungkap yang penting. Sebagaimana terungkap dalam beberapa literatur bahwa ciri sikap masyarakat Jawa Timur adalah lugas, spontan dalam bertutur kata, cepat dalam bertindak, mudah marah dan cepat juga redanya. Jawa Timur dalam sejarah lebih diwarnai oleh peristiwa heroik membentuk masyaraka dengan temperamen yang keras. Kondisi lingkungan itu terangkat keseluruhan dalam kesenian. Ciri karakteristik yang lain ditampakkan pada pemakaian busana tarinya. Interpretasi tentang makna perjuangan menunjuk pada gambaran para pangeran pejuang karismatik setempat pada masa lampau. Orientasi ini didasar oleh penafsiran bahwa pejuang adalah seorang satria (Pattah, wawancara 2001, Oktober 13) dan gambaran itu lebih tepat ditujukan pada tokoh-tokoh pejuang setempat yang sudah melegenda di masyarakat seperi : Cakraningrat, Untung Surapati, Sawunggaling dan para pejuang karismatik Jawa Timur yang lain.

\section{Ragam Gerak dalam Tari Ngremo}

Gerak dalam tari diperlukan untuk kebutuhan ekspresi. Oleh karena itu gerak sengaja dibentuk, ditata, disusun berdasarkan peleburan antara ide rohaniah dan energi kinetik. Dalam istilah yang lain bahwa gerak dalam tari adalah ekspres simbolis yang dibentuk berdasarkan maksud-maksud tertentu.

Tari dihasilkan dari perpaduan antara gerak lahir dan kekuatan batin.

Dengan adanya harmonisasi antara kekuatan jiwa yang diungkapkan melalui bentuk yang berirama itulah lahir keindahan' (Kussudiardjo, 1992: 1-2)

Kekuatan jiwa yang dikehendaki dalam pernyataan Kussudiardjo adalah pengalaman-pengalaman batiniah seniman selama mengarungi hidup di lingkungannya. Dengan dukungan berbagai unsur yang melingkupi, gerak yang berjiwa tersusun dalam satu struktur koreografi. Tari Ngremo mengacu pada gerakan-gerakan alam seperti: gerakan ayam alas, gerakan nglandhak. Gerakan yang menirukan tingkah laku prajurit yang sedang perang dengan perlengkapan senjatanya seperti: ngendewo, lawung, dan variasi-variasi gerak yang lain. Keadaan ini dapat dipahami karena tari Ngremo pada awal tumbuh dan berkembangnya adalah tari Nglana, yaitu tarian yang menggambarkan pengembaraan seseorang untuk mencari kematangan kehidupan mentalnya. Gerak ditarikan dengan pola ruang yang sempit, dan halus dalam pelaksanaannya. Orientasi seniman Ngremo pada masa awal merujuk pada tokoh Janaka pada pewayangan yang mempunyai karakteristik lembut dan sifat pengembaraannya (Pattah, wawancara, 2001: Oktober 13).

Gerakan yang dibentuk melalui peniruan alam ini mendapatkan penghalusan (stilasi) dan perubahan dari bentuk verbal menjadi gerakan untuk kebutuhan ekspresi tari sehingga yang hadir kemudian adalah kesan-kesan dari gerakan alam tersebut. Sebagai sebuah pengalaman pengembaraan, maka gerak dalam tari Ngremo merupakan interpretasi dari penghayatan terus menerus terhadap lingkungan. Dalam kehidupan membudaya, ekspresi tari tidak sekedar menyajikan gerakan keseharian yang bersifat praktis. Gerak yang diwujudkan dalam tari merupakan hasil kegiatan budaya. Gerak dan kesan gerak tari yang hadir adalah cerminan dari keadaan lingkungan dari mana tari itu tumbuh. Keadaan ini seperti digambarkan oleh Sedyawati (1981: 53). bahwa :

Seni pertunjukan tradisional di Indonesia berangkat dari kondisi tempat ia tumbuh dalam lingkungan-lingkungan etnik yang berbeda satu sama lain. Keberlangsungan dari suatu kesenian akan di tentukan oleh lingkunganlingkungan etnik seperti dalam tata cara atau adat yang merupakan hasil kesepakatan bersama secara turun temurun berkenaan dengan perilaku.

Dalam perspektif ini, tari Ngremo adalah bagian dari kesenian tari Jawa yang secara spesifik mempunyai kaidah khas tari Jawa. Sehingga standar nilai yang menyangkut rasa keindahanya ditentukan oleh kaidah tradisi budaya Jawa. Secara garis besar Tari Jawa menurut Sedyawati digambarkan sebagai berikut:

Tari Jawa pada umumnya ditandai sikap dada yang tegap, langkah yang serba tenang, dan sangat lekat dengan tanah, gerak lengan dengan variasi arah yang halus tetapi dengan posisi stabil pada siku, gerak serba halus tertahan berkelanjutan, gerak leher tertoleh dalam variasi, selendang digunakan untuk memperluas kemungkinan bentuk, wajah tenang tidak dimainkan (Sedyawati, 1986: 16).

Menurut hemat penulis, generalisasi tari Jawa menurut Sedyawati ini masih bersifat umum, yakni keadaan budaya tari di seluruh wilayah Jawa yang meliputi Jawa Tengah, Jawa Barat dan Jawa Timur. Sehingga secara umum pula, tari Jawa menurut konsep Sedyawati ini bisa dimengerti sebagai konsep umum tentang tari Jawa, karena kalau kita melihat secara rinci dari masing-masing 
wilayah budaya tari Jawa masih memiliki ciri unik yang membedakan dari wilayah Jawa yang lain.

Jawa Timur yang masih wilayah Jawa ada kesamaan dengan pola yang diangkat oleh Sedyawari tersebut, tetapi ada pula pola yang khusus sifatnya Terkait dengan tari Ngremo dapat diamati pada pola gerak yang ada. Bentuk gerak dari tari Ngremo mempunyai pola-pola gerak yang menggunakan tenaga yang banyak bertumpu pada kaki dengan variasi pada gerak tangan. Sedangkan gerakan tubuh (torso) relatif sedikit dilakukan dan terbatas pada pola gerak-gerak tertentu seperti gerakan pada lambung. Gerakan-gerakan tangan cenderung cepat, tegas dan patah-patah, tetapi terkendali oleh sikap tubuh (torso) bagian dada yang tegap dan tenang. Pola gerak pada bagian kepala terlihat lebih dinamis karena pola yang digunakan adalah cepat dan patah-patah, pandangan atau sorot mata yang tajam. Dapat dicontohkan di sini adalah gerak iket dan sabetan. Iket merupakan bentuk gerak penghubung yang menggunakan pola ruang menyempit dengan garis yang kontras, sedangkan sabetan merupakan pengembangan dari iket dilanjutkan gerakan kaki dengan penggunaan tekanan tenaga yang cepat dan berkesinambungan, dikombinasi dengan gerak kaki kanan terangkat dan bergetar Dengan demikian bahwa tari Ngremo secara umum mempunyai pola gerak yang bertumpu pada kaki dengan variasi gerak tangan yang dinamis.

Untuk melihat karakteristik tari Ngremo diperlukan dengan melakukan analisis gerak, karena ide tari disalurkan diantaranya melalui gerak. Dengan demikian pembahasannya selalu mempertimbangkan gerak-gerak yang hadir dalam tari. Sesuatu yang penting diperhatikan adalah bahwa gerak dalam tar Ngremo tidak bermakna ikonik (keterhubungan perilaku gerak dengan makna verbal) semisal ukel karna disejajarhubungkan dengan sedang mendengar dan sejenisnya. Gambaran tari Ngremo yang secara estetis menciptakan kesan gagah akan disajikan dengan menguraian sikap dasar tari yang melandasi pelaksanaan pola-pola gerak yang penting.

....dan sikap seseorang tidak terlihat tetapi tetap ada saja perilaku verba tertentu yang menunjukkan hal itu. Perilaku yang kelihatan itulah yang dapat diterangkan........(Liliweri, 1991:90)

Sikap yang terwujud dalam perilaku verbal pada pembicaraan ini adalah pola-pola tingkah laku yang terlihat dalam kegiatan menari. Kegiatan menari tidak saja ketika penari melaksanakan gerak tetapi diam atau kesempatan tidak melaksanakan gerak juga merupakan kebutuhan dalam tari. Diam atau tidak sedang dalam melaksanakan pola-pola gerakan tari dalam tari Ngremo nampak jelas pada adeg ketika tancep. Tancep yang diam tetap dalam keadaan membawa emosi tari yang dialiri ide tematik tari Ngremo.

Imaji, Vol.4, No.2, Agustus $2006: 124$ - 144
Melaksanakan sikap dasar yang tepat pada tari Ngremo akan mengantarkan pada pelaksanaan pola gerak yang penting tersebut pada tingkat ekspresi yang utuh yang berorientasi pada nilai kultural. Oleh karenanya kesan gagah, berwibawa, mantap, tegas akan selalu tercermin pada pelaksanaan gerak penting dimaksud. Pertimbangan pemilihan sikap dasar tari pada tari Ngremo sebagai perabot analisis didasari oleh suatu asumsi bahwa sikap gagah, wibawa, tegas dan tenang telah dicapai oleh pelaksanaan seluruh pola ragam gerak yang setelah sebelumnya dibangun terlebih dahulu oleh sikap dasar tari yang dialiri oleh emosi tari dengan persepsi nilai kultural yang lekat dengan heroisme. Asumsi tersebut benar-benar telah dicapai dengan baik oleh para penari Ngremo yang mampu dengan sempurna menghayati nilai-nilai kulutal setempat baik dalam kenyataan empirik maupun yang tercipta dalam wacana budaya sastra maupun perilaku budaya pertunjukan.

Pola gerak yang sudah tersusun membentuk nama pola ragam gerak seperti pola ragam gerak ayam alas, nglandak, nggendewo dan ragam-ragam gerak yang lain karena secara struktur koreografi ragam-ragam gerak tersebut sudah tersusun mengikuti pola ragam gerak tema yang lama tidak dijadikan bagian dari analisis. Namun demikian yang perlu dijelaskan adalah bahwa pelaksanaan sikap dasar tari yang baik membawa perubahan pada unsur-unsur gerak yang mampu menciptakan rasa gerak dan membentuk karakter baru yaitu dinamis dan bersemangat. Perubahan unsur-unsur gerak itu yang dapat dimaknai adalah kekuatan, kecepatan, ketegasan dan kelincahan. Itupun tidak semata-mata diukur dengan teknik hitungan detik atau skon.

Gerak yang lekat dengan ritme gending dapat diukur kedinamisan-nya dengan perasaan yang berlaku di lingkungannya. Sampai secepat, sekuat, dan selincah apa gerak dan musikalitasnya hanya dapat dirasakan oleh komunitasnya sendiri yang sudah terbekali oleh ide-ide tentang semangat dalam wilayah di lingkungannya. Sebagaimana pernyataan Soetomo seorang pengendang tari Ngremo seperti berikut:

'Saya tidak berusaha mengganti gending-gending yang ada dan juga tidak mempercepat irama yang sudah biasa digunakan, karena gending dan irama yang ada rasanya sudah pas dan enak' (Supadmi 1993: 92).

Pernyataan 'rasa-nya enak dan pas' sukar untuk diukur dengan menentukan berapa skon kecepatan irama gending yang diperdengarkan. Karena rasa dapat dipahami dengan penghayatan dan komunitas yang tergabung dalam satu budaya Ludruk dan Ngremo serta masyarakat pendukungnya saja yang mampu memberikan pemahaman atas pernyataan itu.

Diskripsi sikap dasar tari yang dijadikan landasan pelaksanaan ragam gerak sangat diperlukan sebagai bahan analisis karena selain memiliki bentuk, dan 
bentuk dari sikap dasar tari itu sendiri perlu diuraikan yang penjelasannya sangat dibutuhkan untuk mengungkap isi dibalik bentuk itu sendiri. Dengan demikian isi sebagai wujud interpretasi terhadap bentuk merupakan satu kesatuan makna Sikap dasar tari Ngremo yang melandasi pelaksanaan seluruh pola ragam gerak merupakan komponen dari aspek gerakan pada tari Ngremo yang sangat dominan karena sikap dasar ini selalu hadir pada seluruh kegiatan menari. Sikap dasar tari ini menjadi jiwa pada keseluruhan pelaksanaan pola ragam gerak. Oleh karena itu sikap dasar tari Ngremo yang selanjutnya membawa perubahan-perubahan pada unsur-unsur gerak ini dijadikan pilihan perangkat analisis untuk melihat dan memahami karakteristik tari Ngremo secara umum yang lekat dengan nila kulturalnya.

Gerak sebagai analisis dibutuhkan dan dilakukan pada batas menguraikan pola gerak terpilih sebagai kelompok dominan, yakni kemungkinan seluruh elemen tubuh memiliki kesempatan untuk bergerak. Kemudian gerak secara mendasar dihubungkan dengan interpretasi tari sampai pemahaman kualitas dan dalam hubungannya antar berbagai proses pencapaian rasa (Adshead, 1988: 12) Gerak sebagai obyek analisis memiliki makna dan karakter pada dirinya sendiri, maka makna tersebut menuntun peneliti untuk mengamati, menginterpretasi, dan memberikan penilaian pada suatu tari. Artinya tari tidak akan utuh sebagai sebuah kajian tanpa adanya analisis gerak, tetapi juga tidak akan berarti tanpa keterkaitan dengan konteks di luar gerak (Brennan, 1998: 284).

Dipilihnya sikap dasar tari tersebut dipakai untuk melihat kekuatan karakter yang terbangun dalam tari Ngremo dan untuk melihat perubahan unsurunsur gerak yang terjadi ketika sebelum dan sesudah Ngremo mengalami proses pembentukan karakter kepahlawanan. Dengan dipilihnya sikap dasar tari pada tari Ngremo ini karena seluruh elemen tubuh telah siap untuk melaksanakan seluruh pola ragam gerak. Seluruh elemen tubuh yang siap dimanfaatkan untuk melakukan gerakan-gerakan pada tari Ngremo telah dialiri oleh emosi tari yang terpersepsi dan terinspirasi oleh jiwa yang memuat nilai semangat kulturalnya. Oleh karena sikap dasar tari Ngremo ini merupakan jiwa dari pelaksanaan seluruh pola ragam gerak maka selanjutnya dipilih menjadi perangkat analisis.

Sikap dasar tari dalam kaitan ini tidak memiliki pola baku yang tetap sebagaimana nama seperti nama-nama ragam gerak yang sudah ada. Sikap dasa tari ini hadir dalam keseluruhan pembawaan para penari ketika telah siap melaksanakan tarian Ngremo. Namun demikian bukan berarti tidak bisa ditunjukkan mana sikap dasar tari pada wujudnya, sikap dasar tari Ngremo masih dapat dicermati pada setiap komponen gerak maupun bentuk (wujud pembawaan sebagai cerminan dari sikap menari) yang ada. Sikap dasar tari pada tari Ngremo nampak jelas ketika penari Ngremo (Ludruk) pada awal memasuki arena pentas.

Imaji, Vol.4, No.2, Agustus $2006: 124$ - 144
Berjalan mengelilingi arena pentas dengan pandangan mata yang tajam menyapu ke semua arah. Pergelangan tangan kiri dipegang tangan kanan (memainkan pols dekker) dan terlihat menahan nafas di dalam dada. Sikap sebagai seorang yang sedang mempersonifikasikan dirinya seperti para pangeran imajiner yang digambarkan dalam batin.

Pola yang lain nampak tatkala akan melantumkan kidungan. Pola ketika akan melantumkan kidungan seperti itu dinamakan sikap tancep. Tancep adalah berdiri tegak dengan kedua tungkai membuka, pandangan tajam lurus ke depan dan sesekali menyapukan pandangannya ke arah kiri dan ke kanan (mengamati penonton), pinggang didorong ke kepan, dada membusung, nafas teratur dan tertahan untuk menciptakan kesan gagah dan tenang. Dalam analisis sikap dasar ini akan ditunjukkan pada sikap yang disebut dengan tancep .Dari kedudukan sikap dasar tari pada tari Ngremo sebagai pembentuk karakter dari seluruh karakter gerak yang ada maka perabot analisis ditentukan yaitu sikap dasar tari yang tercermin dalam bentuk tancep. Proses pembentukan tancep dan perubahanperubahan pelaksanan pola gerak setelah ide tari Ngremo berkembang menjadi patriotik kepahlawanan secara rinci dapat digambarkan sebagai berikut:

\section{Bentuk Sikap Tancep}

\begin{tabular}{|c|c|}
\hline Nama Sikap & Uraian komponen tubuh \\
\hline Tancep & $\begin{array}{l}\text { posisi tancep adalah badan tegak, tegap, dada membusung, (mongal), } \\
\text { pandangan lurus horisontal ke depan. Tungkai kanan dan tungkai kiri } \\
\text { membuka ke samping. Pinggang (boyok) didorongkan ke depan (ndegeg). } \\
\text { Lengan kiri berkacak pinggang. Lengan kanan menjuntai ke samping kanan } \\
\text { bawah sejajar dengan arah tungkai kanan. pergelangan tangan kanan ditekuk } \\
\text { (ekstensi) keluar, jari-jari nyempurit. }\end{array}$ \\
\hline
\end{tabular}

\section{Bentuk dan Sikap tubuh (torso)}

Badan tegak, tegap, dada membusung, adalah sikap dasar menari yang dimiliki oleh tradisi tari Jawa (Jawa Tengah-Surakarta dan Yogyakarta-) meskipun pada rinciannya dibedakan oleh jenis tarian putra maupun putri, karakter alus maupun gagah. Sikap badan tersebut merupakan dasar adeg tari Jawa yang dilaksanakan secara ketat. Tetapi sikap tegap, dada membusung merupakan pengecualian dari sikap dasar tari masing-masing daerah di Jawa. Di Jawa Timur (di Malang dan di Madura) mempunyai tradisi tari Topeng, orientasi tema ataupun ceritanya bersifat istana sentris dengan mengambil isi ceritanya dari siklus panji dan Mahabarata sama halnya dengan tari tradis Jawa Tengah kraton. Sikap badan tegap dada membusung tidak seperti pada taria Jawa Tengah yang menahan udara (nafas) sebagai medium pembentuk sikap gagah. Di Jawa Timur cenderung 
melepas nafas. Pola, sikap, dan pelaksanaan geraknya mengarah ke depan dada atau perut, berbeda dengan tari Jawa Tengah yang cenderung bergerak ke samping.

Pola dan sikap gerak yang cenderung di depan dada atau perut itu menyulitkan pelaksanaan sikap dada membusung dengan pengisian dan menahan udara atau nafas yang penuh di dada atau di perut. Pelaksanaan gerak tersebut lebih efektif dengan pengurangan atau pengosongan nafas, sehingga penggunaan sikap dada yang membusung pada sikap dasar tarinya tidak kelihatan atau dada membusung pada sikap dasar tari di Jawa Timur tidak terjadi. Gerak yang cenderung di depan tubuh, kesan gagah yang tampak menjadi sangat berbeda dar tari Jawa (Surakarta dan Yogyakarta) yang dadanya membusung terbuka, karena dada membusung membawa dampak udara ke dalam dada. Secara fisik bentunya kelihatan lebih gagah. Pada dekade awal tahun 1920 sampai 1930-an, tari Ngremo sejajar dengan keadaan tari tradisional Jawa Timur secara umum. Meskipun badan sudah tegak tetapi tidak terlihat dada membusung, karena tangan bergerak di depan tubuh, volume gerak cenderung sempit di depan tubuh.

Pada periode pergerakan fisik sampai setelah kemerdekaan tari Ngremo menjadi heroik. Sikap dasar tari Ngremo yang heroik terwujud secara verbal pada bentuk tancep. Bentuk tancep tersebut secara fisik terdapat kesamaan dengan tancep pada tari gaya Surakarta dan Yogyakarta utamanya tancep pada karakter putra gagah yang tegak, tegap dan dada membusung (ndegeg) kuat, gagah, dan nampaka kesan berwibawa. Oleh karena itu tidak mustahil apabila sikap bentuk yang demikian itu benar-benar dapat dirasakan kesan gagah dan berwibawanya. Sikap dasar yang telah terbangun dengan kuat ini selanjutnya mendasari pad pelaksanaan setiap gerak yang ada pada gerak-gerak penting dalam tari Ngremo.

Pembahasan berikutnya kita cermati pada komponen-komponen tubuh yang mempunyai kesempatan untuk bergerak dan sisi perubahan-perubahannya Perubahan yang dimaksud adalah keadaan yang berbeda sebelum dan sesudah komponen-komponen tubuh bergerak (selanjutnya membentuk pola-pola ragam gerak) ini mengalami perkembangan menjadi Ngremo yang heroik. Perubahan itu terjadi pada perkembangan unsur-unsur gerak, seperti: pengolahan ruang, tempo dan ritme, dan tekanan-tekanan (penggunaan energi) yang dilakukan pada ketika penari Ngremo sedang menari di atas pentas. Komponen tubuh yang mempunyai kesempatan untuk bergerak diuraikan secara rinci sebagai berikut:

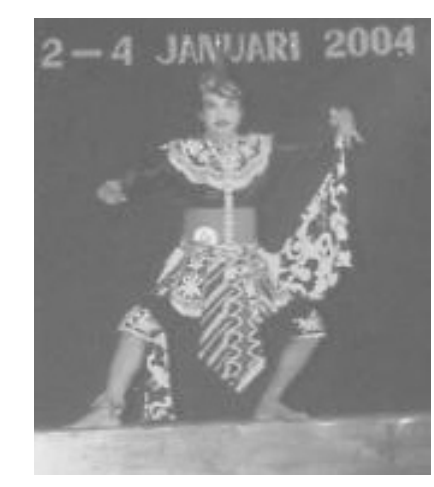

Gambar 1 Tari Ngremo Ludruk yang telah mendapat sentuhan kreatif mencapai

kesempurnaan ekspresi.

\section{Bentuk dan Sikap Gerak Tungkai.}

Sikap kedua tungkai membuka ke samping dan dilanjutkan dengan sikap tajak maka posisi kaki harus mendhak. Bentuk sikap kedua tungkai membuka ke samping mendhak dengan tingkat level rendah yang maksimal adalah sejajar dengan dasar sikap tari Jawa tengah. Sikap kedua tungkai membuka dan mendhak untuk pelaksanaan gerak tari putra gagah meghasilkan kesan gagah dan anteb apabila dilaksanakan dengan benar, yaitu kaki dibuka lebar ke samping (kangkang), lutut kaki kanan dan lutut kaki kiri ditekuk rendah, tumpuan tenaga dibagi dan dipusatkan pada kedua paha (tungkai atas) sedikit berat di paha kiri, pinggang didorong ke depan (ndegek). Sikap adeg tanjak ini menghadirkan kesan kokoh, gagah dan kuat (gambar: 1). Sikap ini membedakan kesan genit karena pelaksanaan sikap yang tidak sempurna, yakni tungkai tidak terbuka dengan baik dan cenderung meringkus. Tari Ngremo saat ini memiliki ciri-ciri pada sikap adeg seperti tari gagah gaya Jawa Tengah yang tegak, tegap dan dada membusung. Volume bentuk tungkai dengan sikap mendak seperti pada tari gagah gaya Jawa Tengah dengan variasi gerak dengan volume yang luas menyamping. Dapat dibandingkan dengan Ngremo masa awal yang mana sikap kaki masih belum semaksimal Ngremo sekarang ini. Dasar gerak dari gerakan tayub (Wibisono, Kanwil Dep P\&K Jatim: 10) yang tidak memperhatikan kesan gagah sehingga mendak yang obtimal belum menjadi orientasi pada Ngremo masa awal. Orientasi bentuk mendak maksimal yang terakhir ini adalah utuk mendapatkan kesan gagah dan mantap. Sebagaimana 'satria' Gatutkaca yang gagah perkasa, gerakannya trengginas, cepat, kuat tetapi tidak brangasan, sikapnya tegas tetapi emosinya terkendali. Tari Ngremo ini seperti satria Gatutkaca tetapi disesuaikan dengan kondisi Jawa Timur. Maka gerakannya sedikit banyak ada unsur pencak silat (Pattah, wawancara, 2003. Pebruari: 13).

'Satria' atau 'kesatria' sesungguhnya berarti prajurit. Terdapat dua macam karakter satria dalam dunia pewayangan, satria dengan temperamen alus dan satria 
dengan watak gagah perkasa. Interpretasi atau penafsiran Munali Pattah memilih sikap satria yang gagah perkasa yakni sikap seorang pejuang, pahlawan nusa dan bangsa, seperti Gatutkaca. Dan tidak lagi menggunakan tokoh Janaka sebagai lelananging jagad dalam memaknai sikap pahlawan. Lelananging jagad adalah simbol manusia (lelaki) ideal dalam konsep 'budaya Jawa'. Seorang yang tampan rupawan (dikagumi banyak wanita), tampan budi (lemah lembut dalam kata dan tindakan), unggul dalam ilmu raga dan ilmu batin, memiliki derajad kebangsawanan bahkan pernah menjadi Raja di kahyangan. Meskipun ke dua satria tersebut tidak digolongkan menjadi satria utama (seperti dalam Serat Tripama) tetapi memiliki sifat sebagaimana seorang satria dan kedua tokoh ini lebih akrab di kalangan pecinta pertunjukan wayang.

Sifat menonjol Janaka sebagai tokoh senapati perang melawan berbagai bentuk ancaman, gangguan, dan agresi, menginspirasi banyak kaum nasionalis Indonesia mengidolakan tokoh ini. Seperti Sanusi Pane, sastrawan kelahiran Muara Sipongi, Tapanuli, Sumatra Barat yang dekat dengan budaya Jawa in menempatkan dan meneladani tokoh Arjuna dalam semangat resistensinya terhadap kolonialis Belanda. Arjuna sebagai pahlawan model yang mendapa wejangan atau pesan moral dari Kresna seperti diceritakan dalam Bagawat Gita untuk tetap bersemangat menuju kancah peperangan. Sanusi Pane yang terpanggil jiwanya untuk berjuang melawan kolonial Belanda menyalurkan perlawanan melalui puisinya berjudul 'Arjuna'. Tokoh satria Permadi atau Arjuna yang alus, lemah lembut, tetapi memiliki sifat tangguh dalam berjuang menegakkan keadilan menginspirasi Sanusi pane seorang sastrawan.

Dalam kerangka tari Ngremo Surabayan, tokoh satria Arjuna ini oleh Munali Pattah kurang dirasakan heroik karena penampilan gerak tidak cukup keras, cepat dan luas. Dinamika tari sebagai penggugah emosi pemirsa menghendaki kualitas rasa yang dihadirkan oleh gerak fisik yang cepat, tegas, keras dengan volume gerak yang luas. Munali Pattah yang akrab dengan institus militer lebih memandang perjuangan bersifat militersistik lebih setara pada penampakan sifat heroik yang gagah dan tegas. Karenanya tokoh Arjuna sebaga orientasi awal berkembang menjadi gagah perkasa dengan memandang tokoh Gatutkaca sebagai sarana reinterpretasi nilai kepahlawanan yang lebih sesua dengan semangat militeristik. Seniman Ngremo merasa lebih tepat apabila satria Gatutkaca yang lekat dengan sikap dan pola gerak gagah (dalam tari Jawa Tengah) diadopsi untuk menyalurkan ide semangat perjuangan meskipun masih diperlukan penyesuaian karakter dan dinamika khas Jawa Timur.

Imaji, Vol.4, No.2, Agustus $2006: 124$ - 144

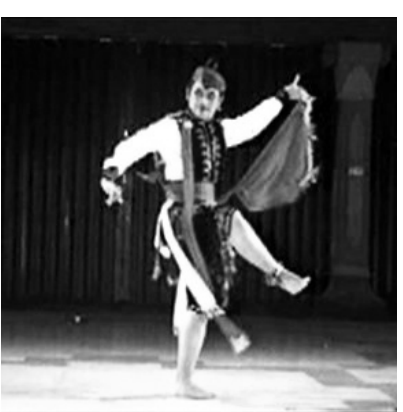

Gambar 2. Gerakan angkat kaki tinggi-

tinggi pada ragam gerak sabetan.

Gerak mengangkat kaki tinggi-tinggi (lihat gambar: 2) juga tidak lazim dilakukan pada masa tari Ngremo masa sebelumnya dan tari Ngermo gaya yang lain. Tari Ngremo sebagaimana kesenian tari rakyat pada umumnya, tidak menggunakan gerak mengangkat kaki sebagai suatu pola fokabuler yang penting. Gerakan ini lazim digunakan untuk tari-tari keraton (Surakarta dan Jogyakarta) jenis putra gagah, untuk penggambaran masyarakat di sekitar lingkungan kerajaan, seperti: raja, para punggawa raja, para satria kerajaan, dan para bangsawan (penguasa) kerajaan yang lain. Sebagaimana perkembangan berikutnya, karena orientasi tata nilai yang di adopsi sebagai ide tari Ngremo berubah, maka orientasi gerak juga ikut berubah menyesuaikan karakter dan penggambaran tokohnya.

Gerakan berjalan sebagai penghubung maupun sebagai pola baku ragam gerak memanfaatkan gerakan labas (berjalan berjingkat) pada tari topeng malang. Ngremo pada awal perkembangannya tidak meng- gunakakn gerak labas tari topeng malang ini, tetapi jalan santai tanpa ada tekanan-tekanan tertentu pada gerakan kaki. Labas lebih mementingkan hentakan kaki ke tanah atau lantai untuk memberikan aksentuasi tenaga dan untuk menghasilkan ketertiban langkah kesesuaiannya dengan pola irama secara keseluruhan. Gerak labas tari Topeng Malang ini kemudian diadopsi tari Ngremo untuk membantu menciptakan dinamisasi gerak dan irama.

3. Bentuk dan Sikap Gerak Lengan dan Tangan.

Sebagian besar pola dan pelaksanaan gerak tangan pada tari Ngemo Surabayan menggunakan atau menciptakan ruang dan kesan gerak yang menyamping. Kalau terdapat proses pelaksanaan gerak yang menggunakan ruang di depan tubuh, pada akhir pelaksanaan pola ragam gerak selalu berakhir dengan sikap garis tubuh dan volume ruang yang luas menyamping (lihat lampiran diskripsi gerak Ngremo). Pola gerak menyamping ini memungkinkan dada kelihatan menonjol ke depan (mongal atau membusung). Keleluasaan gerak tangan ke samping kiri dan kanan tubuh dengan pola-pola ruang gerak yang membentuk garis lengkung, nampak sikap badan dengan kesan tegap dan gagah. 
Sikap dan gerak tangan ke samping kanan kiri tubuh ini lazim bagi sikap dan gerak lengan untuk tari Jawa Tengah dan tidak begitu nampak bagi tari Malang atau tari Topeng Madura kecuali pada sikap tancep. Sebagaimana di sebutkan sebelumnya bahwa orientasi sikap gagah pada tari Ngremo lebih menunjuk pada karakter satria gagah perkasa khas Jawa Tengah. Orientasi ini berlanjut pada penggunaan dan pelaksanaan pada pola gerakan-gerakan tangan. Sebagai ciri khas pada pola gerak tangan adalah gerakan silat yang cenderung cepat, patah-patah, tetapi masih memiliki sifat tenang.

\section{Bentuk dan Sikap Gerak Leher dan Kepala.}

Pada bagian ini meliputi gerak leher atau pacak gulu dan pandangan mata atau pandengan. Pada gerak leher pada prinsipnya ada dua macam bentuk Pertama adalah gerak leher yang disebut godheg yaitu gerak melingkar satu putaran penuh atau setengah lingkaran. Gerak leher (godheg) satu lingkaran penuh dimulai dari arak hadap muka ke depan, diputar ke kiri atau ke kanan satu lingkaran penuh dan berakhir kembali pada arah hadap semula. Gerak leher setengah lingkaran dimulai dari arah hadap ke depan diputar ke kiri atau ke kanan, berhent pada pandangan muka ke kiri atau ke kanan, atau sebaliknya dimulai dari arah hadap muka dari samping kiri atau kanan kemudian leher diputar kekanan atau ke kiri sehingga wajah menghadap ke depan. Gerakan ini dilakukan untuk melengkapi ragam gerak sebelumnya menambah penegasan karakter ragam gerak tersebut.

Ke dua adalah gerak kepala patah-patah, yaitu wajah menghadap ke depan dan kepala direbahkan ke samping kanan dan samping kiri secara bergantian yang dilakukan dengan cara hentakan sehingga menghasilkan gerak Patah-Patah. Gerakan kepala patah-patah ini dilakukan tatkala pada pola bentuk gerak tertentu tidak digerakkan atau dalam posisi diam kecuali gongseng yang terus bergerak bersamaan dengan kepala tersebut. Pola gerak ini menghadirkan sikap gagah, tenang tetapi tetap dinamis.

Pandengan atau pandangan mata secara umum mengarah ke garis horisontal. Yaitu ke arah depan, sudut depan kanan atau kiri, dan ke arah samping kanan atau samping kiri. Sekali-sekali menundukkan pandangan ke arah depan bawah untuk menambah variasi ekspresi muka. Variasai ekspresi mimik atau muka ini memberikan imbangan kepada gerakan-gerakan anggota tubuh yang lain sehingga secara keseluruhan tari Ngremo tampak ekspresif dan dinamis. Lebihlebih pandangan mata yang tajam dengan ekspresi muka yang mengeras dapa menghunjam ke dalam jiwa setiap pemirsa mampu membawa imajinasi penonton pada hayatannya. Ekspresi pandangan mata tari Ngremo ini berbeda dengan ekspresi pandangan mata tari Jawa Tengahan yang cenderung ke dalam.

Imaji, Vol.4, No.2, Agustus $2006: 124$ - 144
Semua harapan dan tujuan untuk mencapai kesan rasa gerak yang selaras, dan penggambaran karakter yang diinginkan dilakukan dengan berbagai cara dan motif serta tujuannya. Misalnya dengan cara perubahan pelaksanaan tempo gerak, aksentuasi tenaga yang menghasilkan gerak patah-patah, dan volume yang luas. Kecepatan gerak merupakan perkembangan penting dari gerak tari Ngremo ini. Sebagaimana dikehendaki oleh sifat tegas dalam mengambil keputusan, wibawa dalam penampilan dan cepat dalam bertindak, maka gerak tari ngremo pelaksanaannya berkembang dari lemah gemulai menjadi cepat, luas, keras dan lebih bersemangat. Kebutuhan itu diperlukan untuk mendapatkan kesan-kesan heroik.

Atas dasar analisis aspek karakter dan gerak yang diajukan dapat dipahami bahwa kesatria sebagai rujukan karakter oleh seniman tari Ngremo diwujudkan secara kinetik melalui gerak. Kesatria sebagai konsep secara empiris didapatkan oleh seniman melalui kegiatan pertunjukan di dalam instansi militer, sikap dasar dan pola gerak terinspirasi oleh sikap dasar tari pada tari Jawa Tengah (Surakarta dan Yogyakarta), sedangkan persepsinya lebih banyak terinspirasi oleh karakter gagah pada satria dalam dunia pewayangan. Keadaan karakter dan gerak pada tari Ngremo Surabayan ini tidak ditemukan pada tari Ngremo Jombang, Malang atau gaya personal daerah lain.

\section{Tata Rias dan Tata Busana dalam Tari Ngremo}

Kebiasaan dalam tari tradisi, unsur-unsur fisual sebagai pendukung terwujudnya maksud dari tema tari dipikirkan secara rinci dan cermat. Tata rias dan busana misalnya menjadi bagian penting dan harus diusahakan pengadaannya. Sebagai perwujudan karakter, maka penampakan secara fisik menjadi perhatian yang khusus. Dalam kaidah Jawa dikenal istilah mungguh yaitu kesatuan bentuk dan isi-nya. Lebih jelasnya:

'Kemungguhan dapat diartikan sebagai ketepatan wujud tari, wujud

kesatuan tari, wujud yang dijelmakan oleh penari dalam sajian tarinya. Wujud tari itu bukan hanya mengenai bentuk (tangguh dan bleger) tubuh belaka. Demikian juga kemungguhan bukan semata-mata ketepatan wujud kesatuan tari yang timbul dari bentuk (bleger) tubuh yang ditarikan penari belaka, melainkan yang timbul dari kesatuan unsur-unsur gerak dan bentuk tubuh dan unsur-unsur penunjangnya, seperti: tata rias, tata busana, tata iringan, tata panggung (setting, dekorasi, dan lain-lain), dan tata cahaya' (Humardani, 1991:31)

"Bentuk (bleger) tubuh memang merupakan salah satu unsur penunjang penting kemungguhan tari, tetapi sama sekali tidak berarti bahwa bentuk (bleger) tubuh itu merupakan satu-satunya unsur yang menentukan kemungguhan tari. Gerak tari atau gerak tubuh yang ditarikan merupakan unsur lain yang tidak kurang 
pentingnya, bahkan dalam tari dapat lebih penting, karena tari pada hakekatnya adalah gerak tubuh yang indah. Demikian pula dengan tata busanan juga dapat membantu kemungguhan", (Humardani, 1991:31).

Dalam kaitan ini tari Ngremo merupakan jenis tarian tradisional yang selalu mengindahkan perwujudan karakter khas sebagaimana dikehendaki oleh tema tarinya. Tata rias dan tata busana terlihat sangat menonjol penampakanya. Munali Pattah mengatakan:

'Rias dan busana tarinya tidak saya rubah, dari dulu ya begitu. Ada dua

model rias busana, model Sawunggalingan dan model Cakraningratan'

(Munali Pattah Wawancara, 2003: 13 Pebruari).

Pernyataan tersebut dapat dijelaskan bahwa tata rias dan tata busana tari Ngremo terdapat dua bentuk perwujudan karakter. Tari Ngremo untuk mewujudkan karakter Sawunggaling dan tari Ngremo untuk mewujudkan karakter Cakraningrat. Kedua tokoh yang sudah melegenda di wilayah Surabaya khususnya dan Jawa Timur pada umumnya dipakai sebagai orientasi tema tari Ngremo Dalam cerita-cerita Ludruk kedua tokoh ini seringkali hadir dalam pertunjukannya, utamanya periode setelah kemerdekaan sampai tahun 1980-an. Menjadi wajar apabila masyarakat cukup kenal dan bahkan akrab dengan kedua tokoh ini sampai pada pemahaman karakternya, sehingga suatu ketika penampakan tari Ngremo yang tidak sesuai dengan karakter kedua tokoh in mendapat tanggapan kritis secara langsung dari komunitas seni pertunjukan tradisional Jawa Timur ini.

Secara tradisional bentuk fisik kedua tokoh tersebut didekati serinci mungkin untuk mendapatkan ciri dan karakter yang khas. Sebagai perwujudan tokoh, tata rias dan tata busana tersebut adalah sarana untuk mengidentifikasi diri, di mana penari mendapatkan gambaran wujud untuk mengimajinasikan figu tokoh yang sedang diekspresikan. Selebihnya adalah untuk menunjukkan kejelasan garis-garis kontur wajah. Dengan demikian penonton akan lebih jelas melihat wajah penari dari jarak yang relatif jauh. Namun pada prinsipnya penggunaan bahan untuk menciptakan kesan tokoh karakteristik tersebut sama, hanya goresan untuk menimbulkan kesan yang membedakannya. Penampakan wujud imajiner wajah kedua tokoh tersebut dapat diamati pada bentuk tata rias sebagai berikut:

\section{Tata Rias Bentuk Sawunggalingan.}

Tokoh Sawunggaling digambarkan relatif masih muda sehingga penampakan wajah kelihatan cerah dan bersih. Alis mblarak yaitu kecil dan tegas, mata tajam dan masih bersinar-sinar. Untuk mendapatkan kesannya, shadow warna coklat muda dioleskan di sudut mata sebagai bayangan. Garis mata menggunakan eye liner untuk menampakkan garis kecil yang tipis. Godeg kecil sejajar dengan mata telinga, warna hitam. Rose (pemerah pipi) merah muda dioleskan tipis di pipi bagian atas tidak terlalu melebar. Kumis coretan kecil (lemet) dan bibir menggunakan lipstick warna merah muda. Visualisasinya nampak seperti (pada gambar 3).

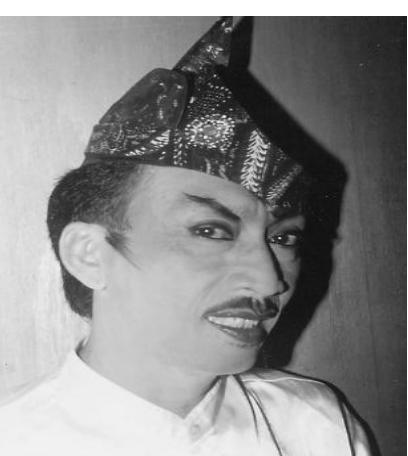

Gambar 3 tata rias sebagai bentuk interpretasi pada tokoh Sawunggaling

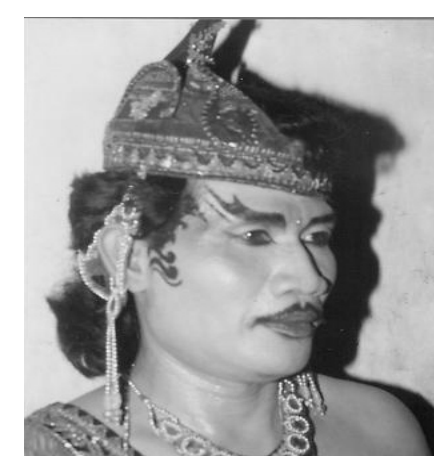

Gambar 4 tata rias sebagai bentuk interpretasi pada tokoh Cakraningrat

\section{Tata Rias Bentuk Cakraningratan.}

Yang membedakan kedua tokoh tersebut adalah tingkat usia dan tempat tokoh berasal. Sawunggaling dari Surabaya dan Cakraningrat dari Madura. Tokoh dari Madura ini digambarkan lebih keras. Penampakan wajahnya diwujudkan dengan goresan rias lebih tebal dan tajam. Alis Mangot (lebih tebal dari Sawunggaling), rose pipi lebih merah dan tebal, godheg rangkap sampai pada jenggot (jambang), kumis lebih tebal dan kadang menggunakan kumis palsu (terbuat dari rambut yang dibentuk menyerupai kumis). Bayangan mata menggunakan shadow gelap, menggunakan celak, dan lipstick lebih merah dan tebal. Visualisasi ini diusahakan untuk mendapatkan kesan karakter yang dewasa, matang, tegas, keras tetapi sedikit lebih tua (hidajat, 1994: 89). Visualisasinya sebagaimana dapat dilihat pada (gambar4).

\section{Tata Busana Sawunggalingan}

Usia relatif lebih muda digambarkan dengan stamina fisik dan emosi yang masih dominan bergelora. Penampakan bentuk fisik masih sehat, berotot, ditampakkan dengan tanpa menggunakan kemeja (ngligo). Tutup kepala kemplengan (tanpa penutup rambut) yaitu iket atau udeng dilingkarkan di kepala dengan tali menjulang ke atas (ditampilkan di kepala bagian belakang). Biasa juga memakai selempang dari jenis kain bludru warna hitam atau merah dengan ornamen bunga atau daun-daunan dari mote atau flasmen. Slempang di kenakan pada bahu kanan melingkar ke pinggang bawah kiri memutar ke punggung dan 
bertemu di bahu kanan belakang. Memakai celana panji dari jenis kain bludru warna hitam atau merah (panjangnya sampai di bawah lutut). Kain jarit (umumnya parang barong warna putih) dengan lipatan wiru di bagian tengah dibentuk seperti dasi atau kupu tarung kemudian diikat dengan stagen melilit di luarnya disusul dengan epek timang. Untuk menambah kesan mewah dan gagah disisipi ricikan boro samir dipasang di paha kanan dan kiri serta kalung penaggalan. Keris bentuk ladrangan diselipkan di pinggang kanan belakang yang di bagian ladrangan diika sampur atau rangkaian bunga melati menjuntai ke bawah. Memakai pols dekker dan atau gelang dikenakan melingkar di kedua pergelangan tangan. Sampur warna merah atau putih diikatkan di epek bagian pinggang kiri, dan kanan dilingkarkan ke belakang, sampur menjuntai ke bawah. Secara fisual dapat dicermati pada gambar 5.

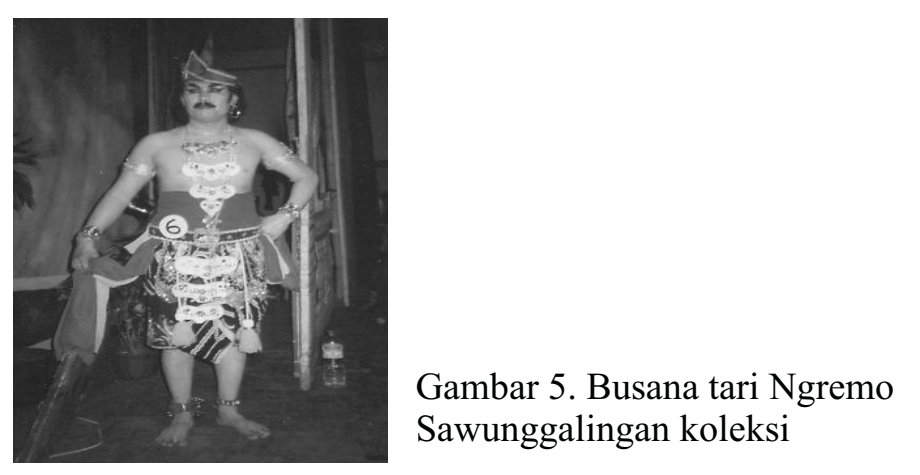

4. Tata Busana Cakraningratan.

Selisih dari busana Sawunggalingan adalah bahwa busana Cakraningratan mengenakan kemeja warna putih kain jenis saten atau kain jenis bludru warna hitam. Tutup kepala menggunakan bentuk tutup liwet yaitu rambut bagian atas tertutup rapat dengan tali menjulang ke atas ditempatkan di kepala bagian belakang. Mengenakan giwang di telinga kiri. Selebihnya sama dengan busana Sawunggalingan. Pemakaian kemeja menambah kesan kematangan dan kedewasaan. Pada busana Cakraningratan ini dilengkapi dengan menggunakan tiruan rompi dan Ther yaitu di pundaknya menyandang tiruan bentuk kepangkatan pembesar militer tentara kerajaan Belanda di Indonesia masa kolonial. (gambar: 6). Munculnya kreasi-kreasi dengan penambahan dan atau penggantian disain, warna atribut-atribut sebagai upaya untuk semakin mendekatkan pada etnik Jawa Timur mulai dilakukan ketika Pusat Latihan Candra Wilatikta pertama kali menampilkan tari Ngremo. Melalui pendekatan sejarah, kelompok baru penggia kesenian tari itu menjelajahi khasanah busana khas Jawa Timur. Melalui pencarian literatur dengan mendatangi candi-candi yang ada di Jawa Timur utamanya Candi

Imaji, Vol.4, No.2, Agustus 2006 : 124 - 144
Penataran ditemukan beberapa atribut seperti rapek (kain bersulam bentuk setengah lingkaran memanjang diikatkan menutupi bagian depan bawah pusat) yang lazim dikenakan pada Topeng Dalang (Malang) (Sunarto AS, wawancara, 2003: 18 April) (Lihat gambar: 6). Busana tersebut merupakan rintisan yang dimulai oleh Yayasan Pusat Latihan Taman Candra Wilatikta tahun 1960-an. Pengembangan busana tari Ngremo tersebut berorientasi pada busana yang dianggap sebagai busana khas Jawa Timur. Usaha pencarian khasanah busana Jawa Timur tersebut dapat dikenali pada candi-candi di Jawa Timur. Sebagai bentuk yang nampak seperti pada gambar 20 tersebut adalah bentuk yang disempurnakan merupakan kebijakan dari Pemerintah Daerah Propinsi Jawa Timur. Pada tanggal 20 Mei tahun 1978 adalah hari peresmian Taman Budaya Jawa Timur yang membutuhkan kehadiran tari Ngremo secara kolosal. Bidang Kesenian menginstruksikan penggarapan tari Ngremo melalui unsur gerak yakni 1) pemadatan gerak (yang relatif panjang untuk diperpendek), 2) penyeragaman tari Ngremo dan busana khas prajurit yang diambil dari khas busana ningrat (bangsawan kerajaan Jawa) dari tokoh Madura yakni Cakraningrat. E. Penutup

Berdasarkan uraian di atas dapat dipahami bahwa tari Ngremo dalam perjalanannya mengalami pergeseran ide tematik yang selanjutnya melahirkan bentuk fisik spesifik dan khas. Khas dipandang dari bentuk yang mencerminkan tari prajuritan ini merupakan perwujudan mutakhir menggambarkan nilai-nilai heroik. Ide tematik diorientasi dari semangat perjuangan para pangeran pejuang setempat di Jawa Timur dalam menegakkan nilai-nilai kemerdekaan. Perwujudan khas sebagai kemungguhan rasa tari dibentuk melalui berbagai pendekatan, utamanya pada aspek visual yakni aspek gerak dan tata rias dan busana. Melalui pendekatan gerak tari Ngremo berkembang dari gerak gemulai menuju gerak cepat, tegas, luas dan mantap. Melaui pendekatan tata rias dan busana tari Ngremo mengidentifikasi perwujudan tokoh-tokoh karakteristik pejuang setempat yakni Cakraningrat dan Sawunggaling. Pendekatan karakteristik ini ditujukan untuk mencari bobot nilai heroik yang gagah dan berwibawa. Karenanya tari Ngremo yang berkembang di Surabaya dan sekitarnya apabila dicermati menunjukkan sifat dan karakteristik khas dua tokoh imajiner pangeran pejuang setempat di Jawa Timur. Tari Ngremo yang berorientasi pada karakter khas tokoh Cakraningrat dan tari Ngremo berkarakter Sawunggaling. Pembentukan karakter yang dilakukan para seniman Ngremo selalu menggunakan rujukan dari sumber-sumber yang mempunyai nilai filosofi, histori dan politis. Akhirnya, penampakan wujud berupa tari Ngremo dapat mengejawantahkan semangat, keinginan dan harapan-harapan masyaraktnya. 


\section{DAFTAR PUSTAKA}

Adshead, Janet. 1988. Dance Analysis, London: Cecil Court.

Brennan, MA. 1998. "Every Little Movement Has A Meaning All Its Own: Movement Analysis in Dance Research". dalam Sondra Horton Fraleigh and Penelope Hanstein, (ed.), Researching Dance evolving Modes Of Inquiry. Pittsburgh: University of Pittersburgh Press.

Danoesastro, R. Soebiono. 1994. "Temu Keluarga Besar Pusat Latihan Kesenian Tjandra Wilatikta”. Surabaya: STKW.

Ellfeldt, Lois. 1977. A. Primer For Choreographere, diterjemahkan oleh Sal Murgianto, (ed.), dalam Pedoman Dasar Penata Tari, University of Southern California, LPKJ Jakarta.

Geertz, Clifford. 1983. Abangan, Santri, Priyayi Dalam Masyarakat Jawa. Terjemahan Aswab Mahasin, Jakarta: Pustaka Pelajar.

Hawkins, Alma M. 2002. Moving From Within: ANew Method for Dance Making, (ed.), diterjemahkan I Wayan Dibia dengan Judul Bergerak Menurut Kata Hati, Jakarta: Masyarakat Seni Pertunjukan Indonesia.

Hendrowinoto, S. 1987. "Ludruk Dalam Berbagai Peran”, dalam Sarinah, No 21 tahun 1987.

Humardani, SD. 1991. "Sekedar Tentang Tari" dalam Gendhon Humardani. Pemikiran dan Kritiknya, Rustopo (ed.).Surakarta: STSI Press Surakarta.

1991. "Rasa Gerak Tari" dalam Gendhon Humardani: Pemikiran an Kritiknya, Rustopo (ed.). Surakarta: STSI Pres Surakarta.

Hidayat, Robby. 1994. "Petunjuk Praktis Tentang Tata Rias dan Busana Tari Remo Untuk Menunjang Pelajaran Tari Daerah Jawa Timur di Sekolah Menengah Tingkat Atas" dalam Abdi Masyarakat. Malang: IKIP Malang.

2001. "Evolusi Remo Malang" Dalam Bahasa dan Seni. 29.1.109-121.

Kasemin, Kasiyanto. 1999. Ludruk Sebagai Teater Sosial, Surabaya : Unair Press.

Koentjaraningrat. 1985. Metode Wawancara dalam Metode-metode Penelitian Masyarakat. Jakarta: Gramedia.

Langer, Susan. K. 1957. "Problems of Art: The Philosophical Lecture”. New York: Charles Scribner's Son. Diterjemahkan oleh FX. Widaryanto dalam Judul Problematika Seni.

Lombard, Danys. 1996. Nusa Jawa: silang Budaya, Bata-batas Pembaratan Jakarta: Gramedia Putaka Utama.

Murgianto, Sal. 1986. Komposisi Tari, dalam Pengetahuan Elemen dan Beberapa Masalah Tari, Jakarta: Direktorat Kesnian.

Peacock, James, L. 1968. Rites Of Modernization Symbolic and Social Aspects of Indonesian Proletarian Drama, Chigago \& London, The University of Chicago Prees.

Imaji, Vol.4, No.2, Agustus $2006: 124$ - 144
Prakosa, Rohmad Djoko. 2001. "Munali Pattah Maestro Ngremo”. Majalah Kidung, Surabaya. Dewan Kenian Surabaya.

Sedyawati, Edy. 1981. Pertumbuhan Seni Pertunjukan, Jakarta: Sinar Harapan. Seri Esni No. 4.

1986. "Tari Sebagai Salah Satu Pernyataan Budaya", dalam Pengetahuan Elementer Tari Dan Beberapa Masalah Tari, Jakarta: Direktorat Kesenian.

Supriyanto, Henri. 1982. Lakon Ludruk Jawa Timur, Jakarta : Gramedia.

2003. "Sarahan dan Kepelatihan Sandiwara Luruk Se Jawa Timur" Makalah, Surabaya: Taman Budaya Jawa Timur.

Tasman, Agus. 1996. "Analisa Gerak Dan Karakter”, Buku Pegangan Kuliah, Surakarta: STSI. 